CATALAN REVIEW

Catalan Review

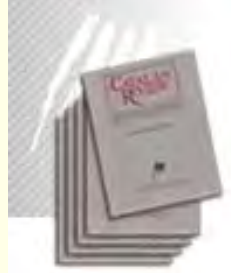

You are accessing the Digital Archive of the Catalan Review Journal.

By accessing and/or using this Digital Archive, you accept and agree to abide by the Terms and Conditions of Use available at http://www.nacs-

catalanstudies.org/catalan_review.html

Catalan Review is the premier international scholarly journal devoted to all aspects of Catalan culture. By Catalan culture is understood all manifestations of intellectual and artistic life produced in the Catalan language or in the geographical areas where Catalan is spoken. Catalan Review has been in publication since 1986 .
NORTH

AMERICAN

CATALAN

SOCIETY
Esteu accedint a l'Arxiu Digital del Catalan Review

A l' accedir i / o utilitzar aquest Arxiu Digital, vostè accepta i es compromet a complir els termes i condicions d'ús disponibles a http://www.nacs-

catalanstudies.org/catalan_review.html

Catalan Review és la primera revista internacional dedicada a tots els aspectes de la cultura catalana. Per la cultura catalana s'entén totes les manifestacions de la vida intel lectual i artística produïda en llengua catalana o en les zones geogràfiques on es parla català. Catalan Review es publica des de 1986.

\title{
Ramon Llull: The Dialogue of Love and Faith William Kluback
}

Catalan Review, Vol. IV, number 1-2 (1990), p. 85-96 


\title{
RAMON LLULL: THE DIALOGUE OF LOVE AND FAITH
}

\author{
WILLIAM KLUBACK
}

In her dialogue with Socrates Diotima reveals a truth about the relationship between the lover and the Beloved. She is pleased by Socrates' description of love because it is not the lover who is dominant, but the Beloved.

I am not altogether surprised - she exclaimed - at your idea of him, which was, judging by what you said, that love was the beloved rather than the lover. So you thought of Love as utterly beautiful, for the beloved is, in fact beautiful, perfect, delicate and prosperous - very different from the lover as I have described him (Symposium, 204 C-D).

Remembering the origin of love we recall the father to be resourceful, and the mother to be needy, devoid of resource and perpetually in search, an absence that reveals the reality of fulfillment. The Beloved draws forth the potentialities that lie in this strange and mysterious union of absence and resourcefulness. But it is the beauty and perfection of the Beloved that arouses the attraction of the lover, driven by a force beyond comprehension the lover discovers the magic of love. The lover no longer rests in his own powers, captured by his sensuous and emotive forces, but like a man in darkness walks naturally towards the fleeting rays of light; the lover is drawn toward a beauty and perfection that has no parallel in his world of momentary pleasure and desires. The lover is not only drawn, but has learned how to receive the love of the Beloved, to accustom his eyes to a light that is more than reflections, a casting of shadows. Slowly, with cultivation, the lover turnstoward the illuminating powers of light that fill the soul, that open the vast expanses of knowledge and reveal to the reason to the memory and the imagination, 
wonders which rational autonomy may hint at, but never achieve.

In that small but precious text, The Book of The Lover and the Beloved, by the Catalan thinker and poet, Ramon Llull, we have a conversation which induces us to look again at the Platonic-Augustinian tradition which held firm to the idea that love begins with the Beloved, that the latter bears within it a mysterious force which attracts what is capable of beauty and perfection, what is liberated from sensuality and pleasure. No work in human history delineated the struggle between the $I$ that seeks the love of the Beloved and the pain and failures of this search, than did Augustine's Confessions. In the eight book of the Confessions Augustine spoke of the sufferings of love.

When I was deliberating upon now serving the Lord my God in accordance with my long intention, it was i who willed, I who was unwilling, to do so. It was I, even I. I was not wholly willing, I was not wholly unwilling. Therefore I strive with myself and I was distracted by myself and this very distinction happened to me against my will and yet did not reveal the nature of another's mind but my own mind's punishment. And yet it was, «no more I that did it" but «sin that dwelt in mew, by reason of the penalty of a sin committed in greater freedom, because I was a son of Adam. ${ }^{\text {I }}$

The love conversation is more than a pleasant and delightful discourse between a yearning soul and a kindly Beloved embellished in pretty and meaningless language that is easily read and pleasantly forgotten. Rather it is the tribulations of a soul in need of grace, of wounds devoid of balm, of pains that find no earthly remedy, and anguish that remains tortuous to the soul in search of comfort and tranquility. The relationship between the lover and the Beloved belongs to those predestined souls whose perseverance overcomes the weaknesses of spirit and body, a price that is far too high for most men.

${ }^{1}$ The Confessions of St. Augustine, trans. C.S.C. Williams (Oxford, Basil Blackwell, I953, VIII, p. 22. 
We listen again to Augustine to grasp the sufferings that are embodied in love and in the lover.

I cast myself down under a certain fig-tree somehow and gave free rein to my tears, and the floods of mine eyes gushed forth, an acceptable sacrifice to Thee, and I besought Thee at length, not indeed in these words but to this effect; and Thou, Lord, how long? How long wilt Thou be angry, forever? Remember not our iniquities of old times for I felt that I was held by them. I continued to utter my sorrowful cries, «How long, how long, tomorrow and tomorrow? Why not now? Why not an end to my uncleanness this very now? Quare non bac hora finis turpitudinis meae? ${ }^{2}$

These beautiful and intriguing lines written with the guidance of the spirit attach us to Augustine's longings and sufferings. These are words that cannot be read indifferently; we are brought within the experience and endure its pain and hidden joys. We feel distraught at the separation that keeps us embodied in our existence and distant from the Beloved. Deep within the self we know that the way to the Divine is beyond our resourcefulness, that Diotima's tale is inadequate and that our way is futile without God's grace.

For simply to will, Augustine knew, to go, meant not only going but arriving there, but it meant to will with resolution not to shake and toss a will half-wounded back and forth while it wrestled as one part of it arose while another part fell... Thus so many things I did where willing did not mean being able; and I did not do that which with a far greater satisfaction would have pleased me more, and which, as soon as I would, I could, for soon to will would mean to will entirely. ${ }^{3}$

There lies in these conversations between the lover and the Beloved the pains of healing. It would seem paradoxical to speak of the pain of healing but in these sufferings experienced by the

${ }^{2}$ Ibid., VIII, p. 28.

${ }^{3}$ Ibid., VIII, pp. 19-20. 
lover there is an opening to a healing that flows from the love of the Beloved. The lover calls to his Beloved:

Come, Lord, and act, stir us up and recall us, inflame and seize us, be fragrant, be sweet to us; let us love, let us run to Thee, amenus, curramus. ${ }^{4}$

The need to love, the need to be drawn closer to the Beloved is the beginning of the recognition of a healing process that commences with man's separation from God, with the disorder that brought turbulence and violence to human life and the alienation of man from the beauty and perfection which is divine love. This love that is the Beloved has no temporal or spatial point; it is everywhere and nowhere.

Woe is me! Augustine cried, How high art Thou in the highest and how deep in the depths! Nowhere too dost Thou depart from us, and with difficulty we return to Thee.

Love is a search for healing, reestablishing man's relationship and dependence upon the Illumination in which his will, his knowledge and his memory find the light which man cannot give himself, but for which he can pray and hope. Knowing his incompleteness and the disorder of his soul it is healing for which he longs, the way which his mortal love, with its resources and needs, can never make it possible for him to travel in a world that has made him a spiritual wanderer and a pilgrim.

The love dialogue that carries within it the intense feeling of man for God had no parallel in Greek classical culture. Diotima's induction of Socrates into the mysteries of love caused us to wonder about the depths of human love, but there was no hint of the personal, divine love that attracted and fulfilled human love. The Confessions of Augustine radically changed the human vision

\footnotetext{
4 Ibid., VIII, p. 9.

s Ibid., VIII, p. 8.
} 
and hope making us aware of our divine dependence, of the interrelationship between knowing and faith and transforming the human virtues through divine inspiration. Augustine spoke in a way that would be utterly foreing to a Greek thinker. It would be difficult to imagine a philosopher saying to God:

You called me; you cried aloud to me; you broke my barrier of deafness. You shone upon me; your radiance enveloped me; I drew breath and now I gasp for your sweet odour. I tasted you, and now I hunger and thirst for you. You touched me and I am inflamed with love of your peace, tetigisti me, exarsi in pacem tuam. ${ }^{6}$

Man describes this love as an embrace, an envelopment, the divine in the depth of unknowability embracing man and filling his presence. The human response remains paradoxical and parabolic. It is profoundly dependent upon grace.

In a magisterial article on Ramon Llull in the Dictionaire des philosophes Louis Sala-Molins delineated the thought of Ramon Llull.

In relationship to The Book of The Lover and The Beloved he said that the mystique of language and rational awareness do not allow the lover any negligence of spirit, never permitting the beloved to solicit him to the point of causing him to lose self-awareness. No herbal wines, ectasies, nor conjugality between the two lovers, but like in all the works of Llull, the constant recreation of a unique love through a endless conscious will and choice by the two lovers. Llull's mysticism is of such peculiar richness and originality, in terms of its historical context, that every attempt to classify it becomes impossible... it is a mysticism which cultivates with tenderness and fury the distance between the lovers because they both know that this distance is indispensable to life and the survival of the love that binds and liberates them at every moment. ${ }^{7}$

${ }^{6}$ Confessions, trans, R.S. Pine-Coffin (Penguin Books, 196I), X, 27.

7 Louis Sala-Molins, Dictionaire des philosophes, $K-Z$. «Raymond Lull» (Paris, Presses Universitaires de France, 1984), 1758. 
This primordial distance that separates the divine and the human is violated in idolatry, in that inordinate desire of man to become God, to overcome his mortality and to arbitrarily assume a divine form. This primal distance Urdistanz creates the reality of dialogue, revealing the sufferings and turbidity that inhabits every human soul that longs for God and knows that $\mathrm{He}$ is unattainable. God's mercy returns man continously to his mortality.

Men know that love is a daemon that permeates every mortal action. Blanquerna thought to himself:

The strength of love knows no bounds when the Lover loves the Beloved with a fervent love. As a result it came to Blanquerna that he should make a Book of the Lover and the Beloved to which the Lover should be a faithful and devout Christian and the Beloved should be God. ${ }^{8}$

Here Ramon Llull begins the tale of the Lover and the Beloved, a powerful and meaningful human condition which is more than what we now understand as a love affair. The love that we have for the Beloved embraces all that we see and do; we are the child and adult of our love, the consequence of the beauty and perfection of the object of our love. We know that everyman attempts love relationships with what is around him. In love he joins to himself what he wants to know, to think and to will. Love is a pattern that brings together all the disparate facts of life, and makes us a part of them. There are no longer abstract objects and subjects, but intimate elements of life which we contemplate with tenderness and intimacy. Love overcomes out tendency to divorce the objects of thought from our feelings and emotions. Love reestablishes our receptivity to creation, and we recreate in ourselves the objects around us, and make them part of our living existence. We return to the world a thankfulness which is possible

${ }^{8}$ Ramon Llull, The Book of the Lover and the Beloved, Kenneth Leech (London, Sheldon Press, 1978), p. II. 
through the love we have for the creator. We love the goodness which the creator gives us in his creation.

In a Sufi prayer we hear the words we pray in our longing to be in love with love, and knowing how rare is such a love. We hear these words:

Unto Thee are we come, by Thine own bringing, where none but Thee suffices us. There is welcome at Thy door and honour in Thy courtyard. Grace at Thy door is the lot of the needy. Though sin has alienated me from Thee, Thou rulest my heart irreplacably. Drowning, Thou knowest all that is in me. Take the hand of Thy drowning one, trusting in Thee. ${ }^{9}$

The lover knows the openness and embrace of salvation that is always in the Beloved, but he also knows that his own love is tainted and inadequate, that he loves the Beloved both willingly and unwillingly, that lust and concupiscence live in his soul. The lover knows the tortures of love that seek to be free of the desires that surround every step and vision of his life. He feels with the Apostle that what he longs to do, he does do and what he does is not what he desires to do.

The richness of the soul in love is like

the paths by which the Lover seeks his Beloved, long and perilous. They are populated by considerations, signs and tears. They are lit up by love. ${ }^{10}$

Llull, like all the great mystic thinkers knew that there is no identity between the lover and the Beloved. Love is always the sufferings of love, but in these sufferings there are joys. Never is the one separated from the other; never does the purity of the divine replace the conflicts of the mortal. In identity there is death, in the negation of mortality there is annihilation.

In a beautiful thought ${ }^{11}$ Llull captured a precious and delicate

${ }^{9}$ The Wisdom of the Sufis (New York: New Directions, 1976), XCVI, 64.

${ }^{10}$ Ramon Llull, The Book of the Lover and the Beloved, p. 13 .

"I Ibid., p. 74 . 
moment of love. He said: The Lover slept, and Love died, for he had nothing on which to love. The Lover awoke, and Love revived in the thoughts which the Lover sent to his Beloved. We touch gently the delicacy of love that must be cultivated and stimulated, that needs our constant attention; quickly do we love our receptivity. We have for so long been separated from the Beloved and so easily we go astray, we neglect and we forget. We are the children of Adam and we are aware of how difficult it is to turn ourselves toward the creator. We are children of forgetfulness and Llull reminds us of this.

Tell us, fool! Where do your needs come from? He answered, from thoughts, from longing, from adoration, from trials and from perseverance. And where do all these things come from? $\mathrm{He}$ answered, From love. And where does love come from? From my beloved. And where does your Beloved come from? From himself alone. ${ }^{12}$

The Fool knows that he will never be free of his earthly existence, of its pains, deceptions and disorders, but he also knows that only in and from these disturbances does he find his Beloved. Those of us who seek paradise, find only hell, and those who search for moral and spiritual progress discover retrogression and violence. In the Beloved we find that sacred dependence in which our knowledge, imagination and memory is rooted. In this primal dependency we find the nature of our mortality, the power that emerges from its longing to overcome its finitude, and to hold back the fascination of idolatry that accompanies our natural search for autonomy and self-glorification.

The Fool speaks the truth.

Tell us, Fool! Would you gladly die? He answered, «Yes, to the pleasure of this world, and to the thoughts of the unhappy sinners who forget and dishonour 
my Beloved. I would have no part or lot in their thoughts because my Beloved has no part in them". ${ }^{\mathrm{I3}}$

In love man discovers a way that leads him from himself to his Beloved. Love is an intermediary leading man from his isolation and lustful attachments to the true object of love, the Beloved. But this movement is created in the lover by the Beloved, through the "seeds" which the latter planted in him. Love is not the spontaneous and autonomous movement of the lover for the Beloved. The movement is from the above to the below and then again from the below to the above. In love man finds the coincidence of opposites.

My Lover - Llull remarked - is ardent and yet fearful, rich and yet poor, joyful and pensive, and every day he grieves because of his love. ${ }^{14}$

Love is a mystery that evokes our fascination. We continually discover that what we say of love we need to say again and again, but always differently and anew. With love there appears the mysterious figure of Diotima who laughs at our foolish questions and yet leads us a step further into the mysteries of a power which no man masters and controls. We each need a guide, a willingness to be open and the capacity to wonder, for in the latter is the beginning of wisdom, and we remain at the threshhold.

We are told that

the Lover built and made a fair city in which his Beloved might dwell. He built it fom love, thoughts, tears, complaints, and griefs. He adorned it with joy, hope and devotion. And he furnished it with faith, justice, prudence, fortitude and temperance. ${ }^{\text {Is }}$

${ }^{13}$ Ramon Llull, The Dialogue of The Lover and The Beloved, p, 78.

${ }^{14}$ Ibid., p. 84.

is Ibid., p. 85 . 
Each life is a dwelling and a furnishing in which we lodge the spiritual and physical possessions of our lives. We are responsible for what we accept and what we deny; it is object of love that determines our choice. But we are sinners and recipients of divine grace; we love but we are not sure of the virtue of our ends. We move from one level of being to another as our philosopher, Plato, described the ascent from the physical to the spiritual vision, from physical beauty to spiritual beauty and to Beauty itself. Plato told us that there was a radical separation between Necessity and Goodness, between immance and transcendence, between the created world and divinity. The movement is never mechanical and orderly; it is through leaps and drives depending on our forces, but more upon those of the Beloved. Every thinker, who thinks with love knows that autonomy is an illusion, that the mysterious flow of forces from the creature to the creator, is paralleled by a movement from the Creator to the creature. Within these ebbs and flows of spiritual powers man finds the sources of creativity and that peculiar and distinct energy which drives him from level to level of life and love. Here he finds the magic of knowledge, imagination and will; here he discovers that the self is not the thinking $I$ but the grace that descends upon it, challenges and strengthens its capacities and desires and at the same time gives it limits and ends.

The love dialogues take on many forms and in Pascal they assumed a rare and beautiful form that again returned to Augustine with an emphasis on man's sinful nature and the overwhelming powers of God's irresistible grace. The dialogue of love and grace dwells within every soul that is embraced by the reality that the reason which ennobled man so fruitfully reaches a higher fulfillment when there is a recognition that the reason must be embraced by grace. Pascal, in a prayer, «Prière pour le bon usage des Maladies», appealed to God with the words: 
Lord what ought I to do to cause you to spread your spirit on this miserable earth? Everything that I am is odious to you, and I find nothing in myself which can please you. I see nothing there, Lord, than my own pains which have some resemblance to yours. Consider the evils I suffer and those which menace me. Glance whith mercy upon the wounds which your hand has made upon me, $\mathrm{O}$ my Savior, who loved your suffering unto death. O God who you made man only to suffer more than any man for the salvation of men! O God you were incarnated after the sin of man and you have taken a body only to suffer in it all the evils which our sins merited!... Love my suffering, Lord, my evils invite you to visit me. To achieve the preparations for your stay, make, $\mathrm{O}$ my Savior, that of my body that has this in common with yours that it suffer for my offenses, my soul has also this in common with yours, that it be in sorrow for the same offenses; and that I suffer with and like you, both in my body and in my soul for the sins I have committed. ${ }^{16}$

In man's search for truth the love dialogue has played a significant role; it has revealed to the generations the intimacy of the divine human relationship, the reality of man's dependence upon God for the fulfillment of his humanity. Deep within man's self-awareness lies the realization of his mortality, both as the belonging and separation from divinity. Man's creativity lies in the cultivation of that inner dialogue between the self and the source of its truth. This dialogue has taken on innumerable forms, but in each there lies the intimate dependence of man upon God, the need to find the source of his truth and the meaning of life that is more than momentary reality and pleasure. Life is a lovegrace relationship which generation after generation sought to expand and comprehend. The significance of this small and precious book of Ramon Llull is that it is a monumental moment in the precious history of love and grace from Plato to Pascal to Soloviev. We read it and we are led in many directions but in them all lives this precious and sacred intercourse of the human and the divine which is the life of faith and love.

The love dialogue is a signum, a sign, of that relationship

${ }^{16}$ Pascal, «Prière pour le bon usage des Maladies» in Ouevres complètes (Paris, Gallimard, 1954), pp. 610-6rir. 
between man and God which is the essence of the "City of God». In this world every love relationship is a pilgrimage, a way towards a city that is only mirrored in this world. The signum points in the direction, it sends us on our way. It shows the inadequacies and ambiguities of the Civitas Peregrina. When we think of Llull's dialogue we discover in it a sign, a memory and an anticipation of the eschatological Kingdom that is ruled by love. The dialogue is a hope and a way, a movement from the Earthly City toward the City of God, the promise of the elect. The dialogue reveals the wanderer among his fellowmen.

WILLIAM KLUBACK The CITY UNIVERSTTY OF NEW YORK 